Gut, 1968, 9, 466-469

\title{
Protein metabolism in the intestinal stagnant loop syndrome
}

\author{
E. A. JONES, A. CRAIGIE, A. S. TAVILL, G. FRANGLEN, AND \\ V. M. ROSENOER
From the Medical Professorial Unit, Royal Free Hospital, and the Department of Chemical Pathology, St. George's Hospital, London

The ${ }^{14} \mathrm{C}$ carbonate method for the direct measurement of the synthesis rates of liver-produced plasma proteins (McFarlane, 1963) is a valuable new technique for the study of protein metabolism in gastrointestinal diseases. It is the purpose of this communication to describe a study in which this technique has been applied to investigate the mechanism of the hypoproteinaemia and disordered protein metabolism which occur in the stagant loop syndrome.

\section{METHODS}

Samples of fasting jejunal contents were obtained using the capsule designed by Shiner, Waters, and Gray (1963) and the samples were cultured both aerobically and anaerobically. Viable bacterial counts were made using serial dilutions (Miles, Misra, and Irwin, 1938). Urinary indicans were measured by the method of Curzon and Walsh (1962).

The distribution ratio and fractional and absolute catabolic rates of albumin were determined by the method of graphical analysis (Matthews, 1957) using human serum albumin (Behringwerke) which had been labelled with ${ }^{125}$ I by a modification of the iodine monochloride technique (McFarlane, 1958). Plasma volumes, used in calculating the intravascular pools of the plasma proteins, were measured using ${ }^{131}$ I albumin.

Concentrations of the plasma aminoacids were estimated using a Technicon amino-acid AutoAnalyzer.

Absolute synthesis rates of albumin and fibrinogen were measured simultaneously by a modification of the ${ }^{14} \mathrm{C}$ carbonate method (McFarlane, 1963). Urea pool sizes and urea synthesis rates were calculated from the curve of clearance from the plasma and the urinary excretion of a known mass of ${ }^{13} \mathrm{C}$ urea (63.5 atoms $\%$ excess), administered intravenously (Craigie, Jones, Rosenoer, and Smallwood, 1967). The ${ }^{13} \mathrm{C}$ atoms $\%$ excess of urea in plasma and urine samples were determined by mass spectrometry in the Department of Biophysics, National Institute for Medical Research, Mill Hill, London, N.W.7.

\section{CLINICAL STUDY}

The patient, a 70-year-old male, presented 10 years after an enteroenteric anastomosis had been performed for small intestinal obstruction due to adhesions from a previous appendicectomy. In spite of eating a diet adequate in both protein $(65 \mathrm{~g} / \mathrm{day})$ and calories $(1,600$ $1,800 \mathrm{cals} /$ day) he had the clinical features of severe protein-calorie malnutrition. He had hypoproteinaemic oedema (plasma albumin concentration $1.5 \mathrm{~g} / 100 \mathrm{ml}$ ) with no proteinuria. There was steatorrhoea (faecal fat $17 \mathrm{~g} /$ day) and a megaloblastic anaemia $(\mathrm{Hb} 11.6 \mathrm{~g} / 100 \mathrm{ml})$ due to deficiency of vitamin $B_{12}$ (serum $B_{12} 10 \mu \mu \mathrm{g} / \mathrm{ml}$, normal 150-900 $\mu \mu \mathrm{g} / \mathrm{ml}$; serum folate $20.8 \mu \mathrm{m} \mu \mathrm{g} / \mathrm{ml}$, normal 6-21 $\mathrm{m} \mu \mathrm{g} / \mathrm{ml}$ ). Tests of carbohydrate absorption and routine liver function tests were within normal limits. A liver biopsy showed a marked excess of fat and lipofuscin. $X$-ray studies of the gastrointestinal tract revealed no abnormalities in the stomach or small intestine. This negative finding was not unexpected as conventional barium follow-through $x$-ray examinations of the small intestine frequently fail to visualize intestinal blind loops which are known to exist.

The finding of a profuse flora of enteric organisms in the fasting jejunal contents (Table I) and a high excretion of indicans in the urine $(250 \mathrm{mg} /$ day, normal $<70 \mathrm{mg} /$ day $)$ indicated extensive bacterial colonization of the small intestine.

TABLE I

BACTERIOLOGY OF FASTING JEJUNAL CONTENTS

Viable Bacterial Counts Antibiotic Sensitivities

\begin{tabular}{|c|c|c|}
\hline $\begin{array}{l}\text { Before } \\
\text { antibiotics }\end{array}$ & $\begin{array}{l}\text { Enterobacteria } 1 \\
5 \times 10^{7} \text { orgs } / \mathrm{ml}^{2} \\
\text { Bacteroides }^{1} \\
2 \times 10^{\circ} \text { orgs } / \mathrm{ml}^{2} \\
\text { Enterococci } 10^{2} \text { orgs } / \mathrm{ml} \\
\text { Lactobacilli } 10^{6} \text { orgs } / \mathrm{ml}^{2}\end{array}$ & $\begin{array}{l}\text { Neomycin S } \\
\text { Tetracycline S } \\
\text { Ampicillin S }\end{array}$ \\
\hline $\begin{array}{l}\text { After } 14 \text { days on } \\
\text { oral tetracycline }\end{array}$ & Enterobacteria $10^{6} \mathrm{orgs} / \mathrm{ml}$ & $\begin{array}{l}\text { Ampicillin } \mathbf{R} \\
\text { Tetracycline } \mathbf{R} \\
\text { Neomycin S }\end{array}$ \\
\hline
\end{tabular}

${ }^{1}$ The Bacteroides, but not the Enterobacteria, were shown to have the capacity to deconjugate bile salts and convert cholate to deoxycholate.

No evidence of increased enteric loss of plasma protein was obtained. The faecal excretion of radioactivity after the intravenous administration of ${ }^{131}$ I PVP was $0.35 \%$ of the injected dose in four days (normal $<1.5 \%$ ) and both the fractional and absolute catabolic rates of albumin were low, $3.7 \%$ of the intravascular pool/day and $25 \mathrm{mg} / \mathrm{kg} /$ day respectively (Table II). 
TABLE II

\begin{tabular}{|c|c|c|c|c|c|c|}
\hline \multicolumn{7}{|c|}{${ }^{125}$ I-ALBUMIN CATABOLIC DATA } \\
\hline & $\begin{array}{l}\text { Plasma Albumin } \\
\text { Concentration } \\
(\mathrm{g} / 100 \mathrm{ml})\end{array}$ & $\begin{array}{l}\text { Intravascular } \\
\text { Pool }(\mathrm{g} \mid \mathrm{kg})\end{array}$ & $\begin{array}{l}\text { Extravascular } \\
\text { Pool }(g \mid k g)\end{array}$ & $\begin{array}{l}\text { Half Life } \\
\text { (Days) }\end{array}$ & $\begin{array}{l}\text { Fractional } \\
\text { Catabolic Rate } \\
(\% \text { IV pool/day) }\end{array}$ & $\begin{array}{l}\text { Absolute } \\
\text { Catabolic Rate } \\
(\mathrm{mg} / \mathrm{kg} / \text { day })\end{array}$ \\
\hline $\begin{array}{l}\text { Patient } \\
\text { Control } \\
\text { Normal range }\end{array}$ & $\begin{array}{l}1 \cdot 5 \\
3 \cdot 8 \\
3 \cdot 5-4 \cdot 6\end{array}$ & $\begin{array}{l}0 \cdot 7 \\
1 \cdot 7 \\
1 \cdot 6-2 \cdot 4\end{array}$ & $\begin{array}{l}0 \cdot 4 \\
2 \cdot 9 \\
2 \cdot 1-4 \cdot 5\end{array}$ & $\begin{array}{l}32 \\
20 \\
14-23\end{array}$ & $\begin{array}{l}3 \cdot 7 \\
9 \cdot 1 \\
9 \cdot 1-12 \cdot 1\end{array}$ & $\begin{array}{l}25 \\
160 \\
136-257\end{array}$ \\
\hline
\end{tabular}

The concentrations of the fasting plasma amino acids are shown in the form of histograms (Fig. 1). The concentrations of several of the essential amino acids were low, whereas those of the non-essential amino acids tended to be relatively normal, a pattern similar to that seen in kwashiorkor (Edozien, 1966).

The absolute synthesis rates of both albumin and fibrinogen were low. The synthesis rate of urea was high and the proportion of this urea recovered from the urine was low (Table III).

RESPONSES TO THERAPY The patient was given a constant diet throughout $(65 \mathrm{~g}$ protein $\equiv 10 \mathrm{~g}$ protein nitrogen, $70 \mathrm{~g}$ fat, and 1,800 calories/day). He was treated with oral antibiotics only. Initially tetracycline (1 g/day) was given and subsequently, after a persistent flora of Entero- bacteria resistant to tetracycline had been demonstrated (Table I), neomycin ( $4 \mathrm{~g} /$ day) was added. The changes in the urinary indicans excretion, body weight (reflecting the degree of fluid retention), plasma albumin concentration, serum cholesterol, faecal fat excretion, faecal nitrogen excretion, absorption of vitamin $\mathbf{B}_{12}$ (Schilling tests with intrinsic factor), and the tryptic activity of the jejunal contents (Lundh meal), which were associated with the antibiotic therapy, are shown in Figure 2. The rise in tryptic activity of the jejunal contents from $3.0 \mu$-equiv $/ \mathrm{min} / \mathrm{ml}$ to $6.8 \mu$-equiv $/ \mathrm{min} / \mathrm{ml}$ (normal greater than $9.6 \mu$-equiv $/ \mathrm{min} / \mathrm{ml}$ ) suggested that the pancreatic exocrine insufficiency was probably not due to primary pancreatic disease.

The concentrations of the fasting plasma amino acids almost all returned to the normal ranges (Fig. 1). The

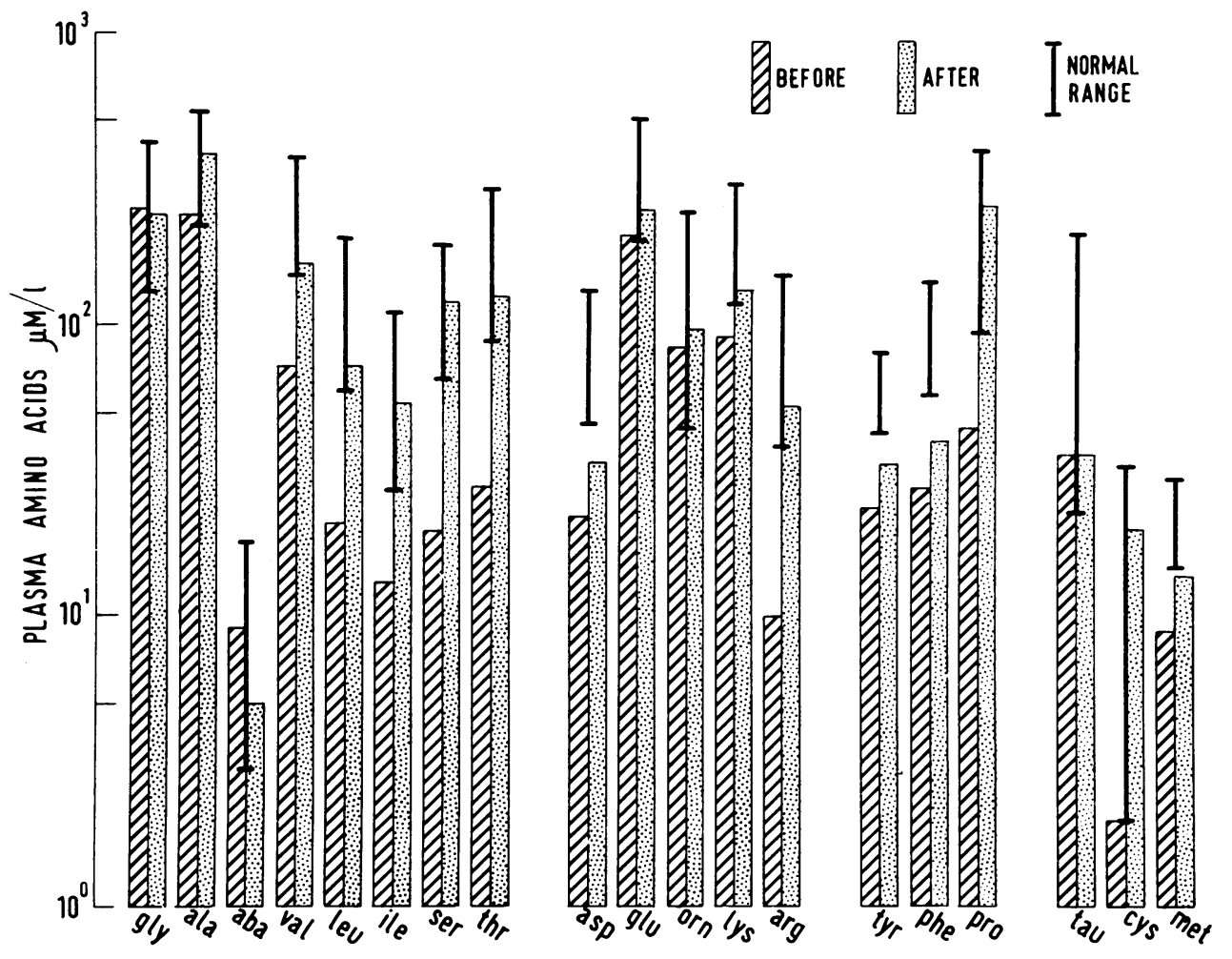

FIG. 1. Fasting plasma amino acids before and after antibiotic therapy. Each amino acid is indicated by the first three letters of its name eg gly = glycine, ala = alanine, except aba = alpha-aminobutyric acid, ile = isoleucene. 
TABLE III

PLASMA PROTEIN INTRAVASCULAR POOLS AND SYNTHESIS RATES AND UREA SYNTHESIS RATES BEFORE AND AFTER ANTIBIOTICS

\begin{tabular}{|c|c|c|c|}
\hline & Normal Range & $\begin{array}{l}\text { Before } \\
\text { Antibiotics }\end{array}$ & $\begin{array}{l}\text { After } \\
\text { Antibiotics } \\
\text { (39 days) }\end{array}$ \\
\hline Plasma albumin concentration $(\mathrm{g} / 100 \mathrm{ml})$ & $3 \cdot 5-4 \cdot 6$ & $1 \cdot 5$ & $3 \cdot 2$ \\
\hline Intravascular albumin pool $(\mathrm{g} / \mathrm{kg})$ & $1 \cdot 6-2 \cdot 4$ & 0.7 & 1.4 \\
\hline Albumin synthesis rate $(\mathrm{mg} / \mathrm{kg} / \mathrm{day})$ & $136-257$ & 40 & 323 \\
\hline Plasma fibrinogen concentration $(\mathrm{g} / 100 \mathrm{ml})$ & $0 \cdot 2-0 \cdot 3$ & $0 \cdot 13$ & 0.26 \\
\hline Intravascular fibrinogen pool $(\mathrm{g} / \mathrm{kg})$ & $0 \cdot 09-0 \cdot 16$ & 0.05 & $0 \cdot 15$ \\
\hline Fibrinogen synthesis rate $(\mathrm{mg} / \mathrm{kg} /$ day) & $29-63$ & 16 & 103 \\
\hline Urea synthesis rate $(\mathrm{mg} / \mathrm{kg} / \mathrm{day})$ & $264-377$ & 672 & 291 \\
\hline Urea recovered in urine $(\%$ of urea synthesized & $\begin{array}{l}\text { Data not } \\
\text { available }\end{array}$ & $33 \cdot 8$ & $67 \cdot 4$ \\
\hline
\end{tabular}

synthesis rates of both albumin and fibrinogen increased to supranormal values. Such high synthesis rates may occur when depleted intravascular and extravascular pools of plasma proteins are being replenished. The synthesis rate of urea fell markedly and the percentage of urea synthesized recovered from the urine increased (Table III).

During the six months following the introduction of antibiotics the plasma albumin concentration varied between 3.3 and $3.9 \mathrm{~g} / 100 \mathrm{ml}$.

\section{DISCUSSION}

Neale, Antcliff, Welbourn, Mollin, and Booth (1967) have described patients with signs of severe

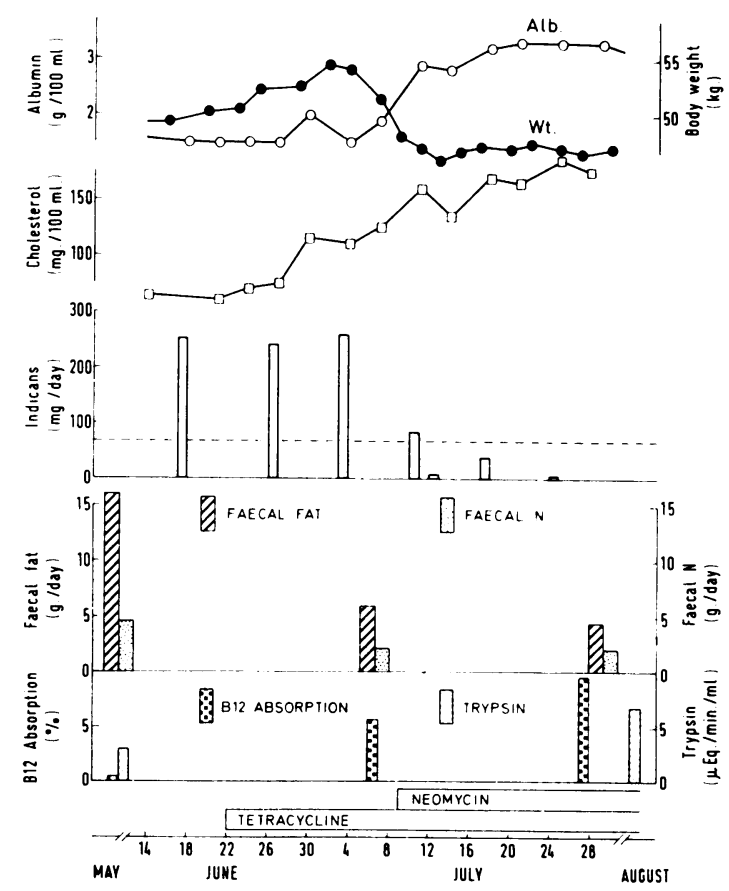

FIG. 2. Responses to antibiotic therapy. protein-calorie malnutrition following partial gastrectomy complicated by either stasis in the afferent loop or pancreatic exocrine insufficiency and have stressed the similarities between this syndrome in adults and kwashiorkor in infants. The adult patient with hypoalbuminaemia described here also showed the clinical features of severe protein-calorie malnutrition. Furthermore the hepatic histology and the pattern of the concentrations of the plasma amino acids were similar to those described in kwashiorkor (Waterlow, 1948; Edozien, 1966), and low levels of pancreatic enzymes in the upper intestinal contents have also been reported in this condition (Thompson and Trowell, 1952). However, the hypoalbuminaemia in this case could not be explained by dietary protein-calorie malnutrition. The finding that the abnormalities of protein metabolism were corrected by oral antibiotics alone suggested that the kwashiorkor-like syndrome had arisen as a direct consequence of the presence of the profuse bacterial flora in the small intestine. The low concentrations of several of the plasma amino acids probably reflected a deficient pool of amino acids and this may well have been causally related to the low synthesis rates of the plasma proteins. Further, the association between the increases in the concentrations of the plasma amino acids and the synthesis rates of the plasma proteins suggests that the replenishment of a depleted pool of amino acids may have been directly responsible for these increased synthesis rates. It is of interest to note that the plasma albumin concentration was subsequently well maintained in spite of the possibility of recolonization of the intestine by antibiotic-resistant organisms.

If the major effect of the enteric organisms on plasma protein metabolism were to inhibit synthesis by the liver cell, one would have expected the concentrations of the fasting plasma amino acids to be high or normal rather than low. Alternatively, if the major effect were inhibition of proteolysis of 
dietary protein, or of the absorption of amino acids across the intestinal mucosal cell, not only would the body amino-acid pool become depleted but one would have anticipated that the resulting state of hypoanabolism and hypocatabolism would have been associated with a low synthesis rate of urea and that this would have increased when antibiotics were exhibited. The reverse was found to be the case. The urea synthesis rate was initially high and was appreciably lower after antibiotics. Before antibiotic therapy the amount of nitrogen incorporated into urea was considerably in excess of the dietary protein nitrogen intake; after antibiotics this was no longer true. Moreover much less of the urea synthesized was recovered from the urine before than after antibiotic therapy.

The data can be explained by postulating that the enteric organisms are responsible for deaminating large quantities of dietary protein with the formation of ammonia, which is then available for absorption and subsequent incorporation into urea. As a direct result of this phenomenon, which could be taking place in both the small intestine and colon, a large proportion of the dietary protein intake may become unavailable for protein anabolism. Further, it appears that an appreciable proportion of the urea synthesized may be hydrolysed by an excess of urease-producing organisms in the intestine. It is suggested, therefore, that in the presence of a profuse intestinal bacterial flora there is a marked enterohepatic circulation of nitrogen. Ammonia passes from the intestine via the portal vein to the liver where it is incorporated into urea, and urea passes from the liver via the general circulation to the intestine where it is hydrolysed. This hypothesis would adequately account for the association of a florid flora of enteric organisms in the small intestine with a state of protein hypoanabolism. The relative extent to which organisms in the small intestine and colon may be responsible for such effects on dietary protein and urea cannot at present be ascertained. Clearly it would be of interest to study urea metabolism in patients who have malabsorption of dietary protein from other causes and a relatively normal enteric bacterial flora predominantly localized to the colon.

\section{SUMMARY}

A study of plasma protein and urea metabolism in a patient with features of severe protein-calorie malnutrition associated with a profuse flora of enteric organisms in the small intestine was made using the ${ }^{14} \mathrm{C}$ carbonate method for the estimation of the rates of synthesis of liver-produced plasma proteins. The concentrations of several of the plasma amino acids were low, the rates of synthesis of two liver-produced plasma proteins were grossly subnormal, the rate of synthesis of urea was high, and the percentage of urea synthesized recovered from the urine was low. All of these abnormalities were either partially or completely corrected by the administration of oral antibiotics alone.

The data suggest that the presence of the organisms in the small intestine may result in (1) the deamination of large quantities of dietary protein resulting in an augmented urea synthesis rate and (2) the hydrolysis of a large proportion of the urea synthesized. The principal effect of the organisms on protein metabolism may consequently be the diversion of a large proportion of dietary protein nitrogen into urea formation with the result that it becomes unavailable for protein anabolism.

The authors wish to thank Dr A. S. McFarlane of the National Institute for Medical Research, Mill Hill, London, N.W.7, for his valuable help and Dr M. Shiner and her group at the Department of Gastroenterology, Central Middlesex Hospital, London, N.W.10, for performing the jejunal aspirations and the Lundh meals.

The ${ }^{131}$ I-labelled albumin used for the plasma volume determinations and the ${ }^{131}$ I PVP were obtained from the Radiochemical Centre, Amersham, Buckinghamshire, England. The human albumin used for determining the catabolic rate of albumin was obtained from Behringwerke, Marburg-Lahn, West Germany. The Technicon amino acid AutoAnalyzer was kindly provided by the M.R.C.

E.A.J. was in receipt of a grant from the Medical Research Council and A.S.T. was in receipt of a grant from the British Empire Cancer Campaign.

\section{REFERENCES}

Craigie, A., Jones, E. A., Rosenoer, V. M., and Smallwood, R. A. (1967). In Proceedings of the Fourth Symposium on the Physiology and Pathophysiology of the Plasma Proteins, Stockholm. To be published.

Curzon, G., and Walsh, J. (1962). A method for the determination of urinary indoxyl sulphate (indican). Clin. chim. Acta,7, 657-663.

Edozien, J. C. (1966). The free amino acids of plasma and urine in kwashiorkor. Clin. Sci., 31, 153-166.

Matthews, C. M. E. (1957). The theory of tracer experiments with 131I-labelled plasma proteins. Phys. in. Med. Biol., 2, 36-53.

McFarlane, A. S. (1958). Efficient trace-labelling of proteins with iodine. Nature (Lond.), 182, 53.

- (1963). Measurement of synthesis rates of liver-produced plasma proteins. Biochem. J., 89, 277-290.

Miles, A. A., Misra, S. S., and Irwin, J. O. (1938). The estimation of the bactericidal power of blood. J. Hyg. (Lond.), 38, 732-749.

Neale, G., Antcliff, A. C., Welbourn, R. B., Mollin, D. L., and Booth, C. C. (1967). Protein malnutrition after partial gastrectomy. Quart. J. Med., 36, 494-494.

Shiner, M., Waters, T. E., and Gray, J. D. A. (1963). Culture studies of the gastrointestinal tract with a newly devised capsule. Results of tests in vitro and in vivo. Gastroenterology, 45, 625-632.

Thompson, M. D., and Trowell, H. C. (1952). Pancreatic enzyme activity in duodenal contents of children with a type of kwashiorkor. Lancet, 1, 1031-1035.

Waterlow, J. C. (1948). Fatty liver disease in infants in the British West Indies. Spec. Rep. Ser. med. Res. Coun. (Lond.), 263. 